\title{
Identification of ERAP1 protein allotypes in the Turkish population and evaluation of their contributions to Behçet's disease risk
}

\author{
EF Remmers ${ }^{*}$, M Takeuchi $^{1}$, MJ Ombrello ${ }^{2}$, Y Kirino ${ }^{3}$, B Erer $^{4}$, I Tugal-Tutkun ${ }^{4}$, E Seyahi ${ }^{5}$, Y Ozyazgan ${ }^{5}$, A Gul ${ }^{1}$, \\ DL Kastner ${ }^{1}$
}

From 8th International Congress of Familial Mediterranean Fever and Systemic Autoinflammatory Diseases Dresden, Germany. 30 September - 3 October 2015

\section{Introduction}

Ankylosing spondylitis, psoriasis, and Behçet's disease are seronegative genetically complex diseases that are also considered complex autoinflammatory diseases. These diseases are characterized by strong association of class I human leukocyte antigen (HLA) alleles and also have a strong contribution to disease-risk by variants of the endoplasmic reticulum-associated amino-peptidase 1 (ERAP1) gene that is limited to individuals who carry the disease-specific HLA class I allele. The ERAP1 protein is responsible for trimming peptides for loading onto HLA class I molecules, which are displayed on the surface of nearly all cells, where they play important roles in immune surveillance and in innate and adaptive immune functions. ERAP1 is highly polymorphic with several SNPs encoding variant amino acids that are likely to influence the nature of peptides bound as well as their ability to be trimmed. These non-synonymous coding variants are not found in isolation, but in combinations or allotypes that act in concert to influence the peptidome available for HLA binding and presentation.

\section{Objective}

To determine the common protein allotypes of ERAP1 in the Turkish population and evaluate their contributions to risk of Behçet's disease.

\section{Materials and methods}

Dense genotyping of the ERAP1 gene region was performed in 1900 patients with Behçet's disease and 1799 healthy controls from previously reported Turkish

${ }^{1} \mathrm{NHGRI}$, Inflammatory Disease Section, Bethesda, MD, USA Full list of author information is available at the end of the article
GWAS and replication studies using the Immunochip. Additional marker genotypes were imputed. Haplotypes of non-synonymous coding SNPs were determined with SVS (Golden Helix) and disease association was evaluated by comparison of haplotype frequencies in cases and controls.

\section{Results}

SNPs encoding ten amino acid variants of the ERAP1 protein were found with minor allele frequency greater than $1 \%$ in 1000 Genomes EUR super-population (ancestral amino acid, position, derived amino acid: T12I, E56K, P127R, I276M, G346D, M349V, K528R, D575N, R725Q, Q730E). These SNPs defined 8 haplotypes with frequency from 2.4 to $23.7 \%$. A single haplotype ( 0.17 frequency) bearing 5 non-ancestral amino acids (V349, R528, N575, Q725, and E730) was associated with Behçet's disease susceptibility (recessive model, OR = $2.55,95 \% \mathrm{CI}=1.70-3.82, \mathrm{P}=3.13 \times 10^{-6}$ ).

\section{Conclusion}

The ERAP1 allotype, T12, E56, P127, I276, G346, V349, R528, N575, Q725, E730, was associated with Behçet's disease. In previously reported studies this ERAP1 variant has been associated with poor peptide trimming. This study supports the hypothesis that a functionally distinct coding allotype of the ERAP1 protein contributes to Behçet's disease risk by altering the production and/or destruction of peptides available for binding class I HLA.

\section{Authors' details}

${ }^{1} \mathrm{NHGRI}$, Inflammatory Disease Section, Bethesda, MD, USA. ${ }^{2} \mathrm{NIAMS}$, Translational Genetics and Genomics Unit, Bethesda, MD, USA. ${ }^{3}$ Yokohama 
Published: 28 September 2015

doi:10.1186/1546-0096-13-S1-P14

Cite this article as: Remmers et al:: Identification of ERAP1 protein allotypes in the Turkish population and evaluation of their

contributions to Behçet's disease risk. Pediatric Rheumatology 2015 13(Suppl 1):P14.

Submit your next manuscript to BioMed Central and take full advantage of:

- Convenient online submission

- Thorough peer review

- No space constraints or color figure charges

- Immediate publication on acceptance

- Inclusion in PubMed, CAS, Scopus and Google Scholar

- Research which is freely available for redistribution

Submit your manuscript at www.biomedcentral.com/submit
C Biomed Central 